Pathologie

PATHOLOGY

\title{
EXISTENCE D'UN NOUVEAU SÉRO-TYPE D' “ ESCHERICHIA COLI " D'ORIGINE PORCINE EN FRANCE : 0149 : K 91 (B) K 88 ae (L) : H 10
}

\author{
N. YALCIN \\ Institut national des Éleveurs Noé \\ 78120 Rambouillet \\ RÉSUMÉ
}

A l'occasion de l'autopsie de deux porcelets, l'auteur a isolé deux souches pathogènes d'Escherichia coli n'appartenant pas aux sérotypes habituels en France.

Le Centre international d'Escherichia coli de Copenhague a identifié ces deux souches comme appartenant au sérotype suivant :

$$
\text { oI } 49: \mathrm{K} \text { 9I, K } 88 \text { ac : H Io. }
$$

Dans cet article, l'auteur donne en outre les résultats d'antibiogramme, d'antibiothérapie et d'immunoprophylaxie.

\section{SUMMARY}

\section{NEW S'TRAINS OF E. COLI IN FRANCE}

In the course of the autopsy of two piglets, the author has isolated two pathogenic strains of Escherichia coli which do not belong to the usual serotypes in France.

The International Center of E. coli in Copenhagen has identified both strains as belonging to the following serotype :

$$
\text { or } 49: \text { K 9I, K } 88 \text { ac: H I го. }
$$

In this article, the author gives the resultats of antibiogram, antibiotherapy and immunoprophylaxis. 